\title{
Chapter 11 \\ Tourist Literature and the Architecture of Travel in Olga Tokarczuk and Patti Smith
}

\author{
Rita Baleiro \\ (iD) https://orcid.org/0000-0002-3188-5150 \\ University of the Algarve, Portugal \& CiTUR, Portugal
}

\begin{abstract}
This chapter analyses two travel narratives within the scope of literature and tourism studies, aiming to explore the motivations to undertake journeying and the experience of (literary) pilgrims. The first is the novel Flights, by Olga Tokarczuk (2007), and the second is "How the Mind Works," by Patti Smith (2017). This chapter defines the umbrella concept of "tourist literature" and takes a cross-disciplinary perspective combining the hermeneutics process with findings from the literature review on tourism studies. The analysis of Flights reveals the touring identity and experience of a pilgrim and reflections about airports, travel guides, tourists, and their syndromes. The analysis of Patti Smith's short story uncovers the touring identity and experience of a literary pilgrim who is strongly motivated to undertake literary-inspired trips towards the authors' places.
\end{abstract}

\section{INTRODUCTION}

Over the last two decades, travel texts (i.e., magazines and guidebooks) and travel stories (e.g., Paul Theroux's and Sara Wheeler's) have been subjects of tourism analysis (Dann, 1999; McWha et al., 2015; Thompson, 2011), under the belief they may strongly influence those who travel and play a valuable role for tourism researchers, providing relevant insights into the touring experience (Robinson, 2004, p. 312). Trusting that the analysis and interpretation of literary texts can also have a profound influence on travellers (Onfray, 2007) and contribute with information about the travelling experience and its motivations (Hendrix, 2014), this chapter focuses on two narratives - tourist literature texts - with two main objectives. The first is to examine the narrators' touring identities and their construction of the travel experience. The second is to provide insights about (literary) pilgrims' motivations and experience,

DOI: $10.4018 / 978-1-7998-8262-6 . c h 011$

Copyright $\odot$ 2022, IGI Global. Copying or distributing in print or electronic forms without written permission of IGI Global is prohibited. 
the act of (literary) travel and some elements of the travelling experience (e.g., airports, travel guides, tourists' syndromes, literary places). As this chapter is written within the cross-disciplinary study area of literature and tourism, the narrative hermeneutics is complemented with findings from a literature review on tourism studies.

Literature and tourism studies focus on the intersections between literature and tourism, and their starting point is considered to be the mid-1980s after the publication of Richard Butler's "Literature as an influence in shaping the image of tourist destinations" (1986). Since then, several researchers have explored the various links between literature and tourism by investigating tourist literature texts (Fonseca, 2020; Rodrigues, 2020), combining literary analysis and the concept of literary tourism (Alves, 2016; Oliveira, 2016) and designing literary trails (Almeida, 2016; Machado et al., 2020). Researchers have also studied literary places (Jiang \& Xu, 2017), the construct of authenticity (Earl, 2008), the potential of literary tourism for local development (Hoppen et al., 2014) and literary tourism products and experiences (MacLeod, 2020). However, recent studies confirm that there are still scarcely researched topics (Çevik, 2020), namely the experience and motivation to go on literary travels (Macleod, 2020).

Thus, this chapter seeks to address this gap in the research by analysing and interpreting two travel narratives. In other words, two tourist literature texts. Tourist literature is an umbrella concept that refers to the corpus of literature and tourism studies. As such, the first section of this chapter focuses on presenting its definition. The two following sections showcase the analysis and interpretation of the selected literary texts, that share distinctive attributes of tourist literature. The first is Flights, by Olga Tokarczuk (2007), the winner of the Nobel Prize for Literature in 2018. Originally written in Polish, the book bears the title Bieguni, a noun that refers to an obscure and possibly fictional itinerant Slavic sect, who survived on the kindness of strangers and shared the belief that being in constant motion was the strategy to avoid evil (Kassabova, 2017). This novel merges a collection of voices and stories across time and space, and it portrays the experience of a pilgrim, her motivations and those she encounters, in a constant praise for "the crossing of boundaries as a form of life." (Charles, 2019). The second text, "How the mind works", by Patti Smith (2017), is a narrative which depicts a literary pilgrim's travel experience in France and England, investigating the minds, workspaces and gravesites of writers, searching for the places where she may emotionally encounter her favourite authors. The final section summarises the analysis of the two literary texts and highlights similarities and differences in the narrators' touring identities, experiences and motivations.

\section{THE CORPUS OF LITERATURE AND TOURISM STUDIES: TOURIST LITERATURE}

Within the process of identifying and selecting the corpus of literature and tourism studies, one main concept stands out: tourist literature. This refers to the literary texts involved in the "production of tourist space through travel narratives" (Robinson, 2004, p. 304), in the sense that they enclose spatial representations that can add value to places as tourist attractions. This definition reflected the perspective of cultural geographers. In 2014, the concept was further expanded by Harald Hendrix (pp. 19-29), who coined the term "tourist literature". According to this researcher's view, tourist literature describes the literary texts that can resignify space and foster literary tourism, motivating readers to visit places and landscapes associated with either the presence or memory of literary authors or with literary fiction representations (Hendrix, 2014, p. 22). Well-known examples of such literary fiction are the Brontë 
13 more pages are available in the full version of this document, which may

be purchased using the "Add to Cart" button on the product's webpage:

www.igi-global.com/chapter/tourist-literature-and-the-architecture-of-travel-inolga-tokarczuk-and-patti-smith/292597?camid=4v1

This title is available in Advances in Hospitality, Tourism, and the Services Industry, Business and Management e-Book Collection, Business Knowledge Solutions e-Book Collection, e-Book Collection, Social Sciences and Humanities e-Book Collection, Social Sciences Knowledge Solutions e-Book Collection. Recommend this product to your librarian: www.igi-global.com/e-resources/library-recommendation/?id=132

\section{Related Content}

Exploring Intangible Heritage Marketing in Tourism: A Case Study of Kalaripayattu

Attambayintatvida Vinodan and Sethumadhavan Meera (2019). Conservation and Promotion of Heritage

Tourism (pp. 180-201).

www.igi-global.com/chapter/exploring-intangible-heritage-marketing-in-

tourism/213402?camid=4v1a

Hospitality and Tourism Management: Advanced Issues and Implications

Kijpokin Kasemsap (2018). International Journal of Tourism and Hospitality Management in the Digital Age (pp. 37-52).

www.igi-global.com/article/hospitality-and-tourism-management/210467?camid=4v1a

Conclusion

(2020). Ecotourism and Community Intervention: Emerging Research and Opportunities (pp. 222-244). www.igi-global.com/chapter/conclusion/241996?camid=4v1a

The Role of the UNWTO in Visa Facilitation: The Diverse Impacts on Tourism Industries of China, Russia and Turkey

Ebru Tekin Bilbil (2017). International Journal of Tourism and Hospitality Management in the Digital Age (pp. 17-35).

www.igi-global.com/article/the-role-of-the-unwto-in-visa-facilitation/177120?camid=4v1a 